\title{
ONE TALE OF PROPERTY, IN MY OWN WORDS
}

\section{KATE GALlOWAY*}

Abstract

The power of the State to alter the conditions of use of land through planning laws continues to attract attention and theorisation in terms of the possible intersection between planning and property. As planning laws become more complex, and by needs responsive to environmental degradation-including the consequences of climate change-land owners will arguably suffer loss in terms of the market value of their land even as the broader community might benefit. This article analyses the contention that land planning regulation is itself property-a claim made by Paul Babie in this journal in 2016. It does so in four parts, focusing on the way in which the law itself constructs concepts of both real property and of planning permissions. It analyses the nature, content, and source of the estate in fee simple in Queensland, followed by analysis of James Penner's 'bundle of rights' argument to ascertain whether planning laws might feasibly be comprehended within this conception of property. It goes on to assess a planning permission in terms of Honore's incidents of property before establishing the nature, content, and source of planning rights. Finally, it distinguishes the role of planning law in responding to climate change, suggesting that it is downstream liabilities rather than front-line environmental protection that is at stake. In conclusion, it posits a conceptualisation of property alternative to Babie's own conceptualisation.

\footnotetext{
*Associate Professor, Law, Bond University.
} 
In 2016, the Griffith Law Review published an article authored by Paul Babie purporting to interpret a blog post of mine published back in $2014 .{ }^{1}$ My post commented on actions taken by the then Deputy Premier of Queensland, Jeff Seeney, who had used his executive power to overturn a planning provision of the Moreton Regional Council. The Council had previously passed a rule constraining building permissions on waterfront land. The aim of the Council's planning provision was to avoid potential council liability into the future, in light of likely rising sea levels consequent upon climate change. Mr Seeney's Direction overturned the Council planning provision.

At the time, and in defence of the Direction, media reports had Seeney claiming that the Council's planning provision breached owners' property in their land. While not doubting the government's power to alter the planning law, I maintained in my post, and I still do, that a planning law while a form of regulation that might affect the way in which real property is enjoyed, is not property as Seeney claimed.

In his article, Babie not only disagrees with my contention, but he appears also to suggest that I was in fact making a different argument from that clearly stated in my post. He claims that 'it is unlikely that Galloway intended to separate regulation from the concept of property', subsequently telling the reader what my argument 'really' is. ${ }^{2}$ By contrast, Babie's argument is that 'regulation is property'. 3

In this article, I correct the record by restating and expanding on my argument in my own words. I offer a justification for my stance as a question of law, supported with reference to property theory, and in doing so I counter Babie's arguments. Despite Babie's contention about my meaning, I did indeed intend to 'separate regulation from the concept of property'.

\footnotetext{
${ }^{1}$ Babie (2016), citing Galloway (2014).

${ }^{2}$ Babie (2016), p 612.

${ }^{3}$ Babie (2016), p 612 (emphasis in original).
} 
That was the point of my original post. My response to Seeney's direction was a lawyerly one: I played a straight—largely positivist—bat. Babie reframed my arguments from an abstracted and theoretical perspective that my original post never intended.

To be clear, I do not disagree with Babie's theoretical framing of the issue. However, my contention — as originally stated and not as reinterpreted by Babie—-stands. To clarify also: I do not suggest that the separation of property and planning (including land, resources, and environmental management) is necessarily right. Indeed, I have written before about the problems associated with the failure of law to take a holistic view of land and an expanded conception of property. ${ }^{4}$ To this extent, I have sympathy for Babie's attempt to suggest that managing climate change will depend upon increasing incursions into private property—or the reframing of the content of private property-for the common good. ${ }^{5}$ But in his article, Babie represented the ideas I expressed in my blog post in a way that I did not intend and contrary to what the words themselves suggested. This article returns to my intent, with a far more modest scope (largely descriptive of the law) than suggested by Babie's (abstracted theoretical) response.

This article comprises five parts. In the first part I identify the content and source of real property as a question of law, including its qualitatively different nature and differential source relative to the planning laws that constrain the mode of enjoyment of one's interest in land. The second part draws on Penner's 'bundle of rights' argument $^{6}$ to demonstrate why it is mistaken to assume that a right to build comprises an identifiable, discrete, right in real property. While rights in freehold land might themselves be conceptualised as a 'bundle' in

\footnotetext{
${ }^{4}$ See, eg, Galloway (2012); Galloway (2015).

${ }^{5}$ Babie (2016), pp 609-610.

${ }^{6}$ Penner (1996).
} 
that there is more than one right, the preferable interpretation of that bundle is as a unified whole, established by the State upon the grant in fee simple.

The framing of Babie's argument is unclear about whether the 'right to build' comprises part of the so-called bundle of rights inherent in the fee simple estate. It is possible to suggest that the right to build is construed in itself as property. I have therefore in the third part used Honore's own incidents of property, ${ }^{7}$ invoked by Babie, ${ }^{8}$ to analyse the extent to which a right to build might itself constitute property. In the fourth part I then establish the nature and content of planning rights to differentiate them from property.

In the final part I suggest that Babie's appeal to climate change as the unifying rationale for our apparently sharing a united conception of property, is in this instance, a diversion from the true intent of my original post. I then conclude this article by suggesting that Babie's contention - that Seeney and I were effectively saying the same thing about property — differs both from my original words, and my argument here, because while we may share an understanding of the concept of property, for the purpose of this case study, we hold different conceptions.

\section{The 'Content' of Real Property at Law}

As with my original post, I seek here to engage with land law in Queensland - and not property more generally. Derived from common law doctrine, Queensland real property law will be familiar, no doubt, to other common law jurisdictions and will certainly resonate in other Australian states. In particular, my discussion here centres on the freehold estate in fee simple. It is the freehold estate that was the subject of the Moreton Regional Council's

\footnotetext{
${ }^{7}$ Honore (1961).

${ }^{8}$ Babie (2016), p 605.
} 
original planning provision, and therefore also of the State Government's Direction for its reversal.

The estate in fee simple is the greatest estate known to the law- 'the highest and largest estate that a subject is capable of enjoying'.${ }^{9}$ Contrary to an intuitive assumption about property in land, technically the estate is not ownership of physical land itself. Rather the estate is the far more abstract notion of a legal right to possession of the land. ${ }^{10}$ Further, and what gives an estate its characteristically broad extent, is that it will last for an indeterminate period of time. ${ }^{11}$ Lastly, the common law is clear that the right of alienation is intrinsic to the estate itself, and the courts will strike down an attempt to restrain alienation. ${ }^{12}$

Regardless of the theorisation of the concept of property that might underlie diverse interests in land, and regardless of the contentions of government ministers, ${ }^{13}$ these three factors: a legal right to possession, its indeterminate term, and freedom of alienation, constitute the estate in fee simple as a question of law.

In terms of my statement in the blog post that 'ownership' in land is widely conceived of as a bundle of rights, there are clearly a number of ways in which the freeholder might deal with the composite rights that comprise their fee simple. The legal right of possession might be alienated by transfer of the freehold, or a right of possession granted for a fixed or determinate term ${ }^{14}$ (ie the land might be leased). Rights of user such as easements might be granted, or the land might be put up as security. In this way, the freehold estate might be fragmented into multiple co-existing interests. The rights that comprise the grant however are

\footnotetext{
${ }^{9}$ Blackstone (1765-1769), Book 2, Chapter 11. See also Gumana v Northern Territory (2007) 158 FCR 349, at [83]; Commonwealth v New South Wales (1923) 33 CLR 1, at 42.

${ }^{10}$ Mabo v Queensland (No 2) (1992) 175 CLR 1, at 80-1, 122; Maitland (1909).

${ }^{11}$ Walsingham's Case (1573) 2 Plowd 547, at 555. See also Edgeworth (2017), pp 106-107.

${ }^{12}$ Such a right is 'traceable as far back as the statute Quia Emptores 1290': Edgeworth (2017), p109.

${ }^{13}$ Such as those of Mr Seeney: 'Jeff Seeney Orders Moreton Bay Regional Council to Remove References to Climate Change-Derived Sea Level Rises From Regional Plan' ABC News Online, 9 December 2014.

${ }^{14}$ Radaich v Smith (1959) 101 CLR 209.
} 
derived from the terms of the State grant which at the outset, establish the boundaries of the freehold estate - the real property.

In his article, Babie has, however, extrapolated from the State's role in establishing the boundaries of the freehold estate to explain that my argument was really that:

what Seeney is saying in issuing the direction, apart from recognising the power of the state to shape what property means, is that the state ... was going to take no action to prevent landholders from acting in ways that might cause negative externalities for other Queenslanders. Or ... that the Queensland government would take no action to address the consequences of climate change. ${ }^{15}$

As Babie claims that 'regulation is property' and that Mr Seeney and I are in fact in agreement that restricting a 'right' to build restricts property, it seems that underpinning his restatement of my argument is an assumption that the State, through regulation, will continue to shape the content of property rights after the original grant of freehold.

Certainly, it was my contention that the State has power to shape what property means. ${ }^{16}$ However, I did not intend to imply that the State through building or planning regulations would continue routinely to shape real property rights following the grant. My view was and remains simply that the source of all land grants in Queensland is the State. ${ }^{17}$ In granting land, the State exercises its radical title, perfecting full beneficial ownership and creating an estate in fee simple. ${ }^{18}$ The content, or constituent rights of - property in - that estate are prescribed by common law, statute, and the terms of the grant itself. ${ }^{19}$ The State

\footnotetext{
15 Babie (2016), p 612.

${ }^{16}$ Galloway (2014).

${ }^{17}$ Land Act 1994 (Qld), s14.

${ }^{18}$ Mabo v Queensland (No 2) (1992) 175 CLR 1, at 81.

${ }^{19}$ See, eg, Edgeworth (2017), pp 108-109.
} 
routinely reserves certain rights ${ }^{20}$ and has historically imposed terms upon the grantee as to the use of the land, to promote the development objectives of the State. ${ }^{21}$ The State's radical title effectively assures it an ongoing interest in the land as a disaggregated aspect of its sovereign power, and the right to resume land is inherent in the State - an incident of its radical title. ${ }^{22}$ The State thus retains a right to take land, and to constrain its use according to principles of good governance. ${ }^{23}$ My contention is thus that the nature and content of the collection of rights comprising the estate in fee simple is shaped by the State through the terms of the initial grant and its reservations.

It is true also, that the State may exercise its power to add to or take away from the rights comprising the freehold estate. For example, the Greenhouse Gas Storage Act 2009 (Q1d) and the Geothermal Energy Act 2010 (Q1d) each provide for access to freehold land, for the holder of an authority ${ }^{24}$ or a tenure ${ }^{25}$ respectively. Such access provisions constitute an exception to indefeasibility under Queensland's Torrens statute where access has been granted before the titleholder became the registered proprietor. ${ }^{26}$ Such rights of access therefore intrude into the original terms of the State grant of fee simple, and through their expression as an exception to indefeasibility are recognised as interfering with real property rights.

This example illustrates the power of the State to continue to shape the content of property in freehold, where the sum of rights is reduced to the extent of the new exceptions to indefeasible title. It might be argued that the revised boundaries of the landowner's real

\footnotetext{
${ }^{20}$ See, eg, Land Act 1994 (Qld), Chapter 2, Part 2; Greenhouse Gas Storage Act 2009 (Qld), s28; Geothermal Energy Act 2010 (Q1d), s29.

${ }^{21}$ See, eg, Christensen et al (2008).

22 See, eg, Edgeworth (2017), p 1157.

${ }^{23}$ See, eg, Longo (1983).

${ }^{24}$ Greenhouse Gas Storage Act 2009 (Q1d), s291.

${ }^{25}$ Geothermal Energy Act 2010 (Q1d), ss20-21.

${ }^{26}$ Land Title Act 1994 (Qld), ss 185(1)(i), (j).
} 
property arise through State regulation, which might support a contention that regulation per se is property. However, the content of both the interests created in geothermal and greenhouse gas storage resources (for example) and the way in which they were created, are more likely to paint them as property than permissions under a planning scheme. Unlike planning permissions, their standing as property is reflected in the bounds of the indefeasible title which itself reflects the content of property in freehold. However, if new exceptions to indefeasibility are regulation, and if 'regulation' was in this example 'property', it does not follow that all regulation is necessarily property.

In addition to substantive real property rights, there may also be diverse incidents associated with an estate in fee simple. For example, co-owners as between themselves hold a range of rights including a right to possession of the whole, ${ }^{27}$ and a right to an account of profits. ${ }^{28}$ Joint tenants hold a right of survivorship. ${ }^{29}$ However, despite the nexus of these rights with land and the owners, and their role in mediating relations between the parties, none of these rights is properly considered property. ${ }^{30}$ They are rights that are attendant upon real property but they are not property per se.

Similarly, planning permissions are not considered to constitute real property. For example, in Uniting Church in Australia Property Trust (NSW) v Immer (No 145) Pty Ltd, ${ }^{31}$ the Court considered the nature of transferrable development rights - otherwise described as 'transferable floor space'. These rights derived from zoning regulations so that where an owner of land was prevented by planning restrictions from using to the fullest extent the

\footnotetext{
${ }^{27}$ Wright v Gibbons (1949) 78 CLR 313; Peldan v Anderson (2006) 227 CLR 471.

28 Property Law Act 1974 (Q1d), ss42-43.

${ }^{29}$ Wright $v$ Gibbons (1949) 78 CLR 313.

${ }^{30}$ For an analysis of the right of survivorship as property, see Richardson and Galloway (2009).

31 (1991) 24 NSWLR 510. While the decision as to the status of the parties' contract was overturned in Immer (No 145) Pty Ltd v Uniting Church of Australia Property Trust (NSW) (1992/93) 182 CLR 26, the nature of property in the transferable floor space was upheld, at 32-33.
} 
permissible floor space for buildings on that land, they can transfer the 'surplus' to another parcel of land. The question in this case was whether these rights (to transfer unused development potential to another site) were interests in land.

The Court held that transferable development rights are not interests in land. ${ }^{32}$ Such rights merely allow one landowner to confer a benefit on another landowner (the right to develop land more extensively than they would otherwise be permitted). Certainly, and aligned with Babie's broader contention, transferable development rights in this case were found nevertheless to be proprietary rights: 'They are transferable, and I assume transmissible; they are of large commercial value; and I see no reason why they are not "proprietary" rights in the same way as ... patents or shares in a company are "proprietary" rights. ${ }^{33}$

If Babie's contention is that the right to build forms part of the incidents of the freehold estate, then Immer would contradict this argument. Adopting the reasoning of Meagher J the Moreton Regional Council planning permission (to build) is not transferable, nor transmissible - although it might afford some additional value to the owner of the land to which it attaches. On this reasoning however, it is unlikely that such a right will be found to constitute an interest in land regardless of its likely effect on land value.

Babie argues that 'regulation is property'; that property does not exist without regulation. ${ }^{34}$ The implication of his argument is that he subscribes to Seeney's position, namely that there exists a 'right to build' that is a property right, and that the State may alter that property, through regulation, to avoid harm to others. ${ }^{35}$ I agree that the State has power

\footnotetext{
${ }^{32}$ Uniting Church of Australia Property Trust (NSW) v Immer (No 145) Pty Ltd (1991) 24 NSWLR 510, at 511.

${ }^{33}$ Uniting Church of Australia Property Trust (NSW) v Immer (No 145) Pty Ltd (1991) 24 NSWLR 510, at 511, per Meagher J.

${ }^{34}$ Babie (2016), p 601.

${ }^{35}$ Babie (2016), pp 601-602.
} 
to create the boundaries of what comprises an estate in fee simple, and where it retains a right to resume property. This does align with Babie's idea of an 'inherent choice architecture of property law' ${ }^{36}$ However, the legal framework of real property in Queensland - the architecture of real property — does not, in general terms, seem to accommodate the kind of ongoing alteration of the 'content' of the freehold estate, nor to establish a standalone planning permission as real property per se.

Alternatively, if the 'content' of the freehold estate might be more accurately described as a bundle of rights beyond the scope suggested here, the more theoretical possibility arises that the 'right to build' comprises one of the 'sticks' in the bundle that constitutes the estate in fee simple.

\section{Fee Simple as a Bundle of Rights}

Despite the popularity of the bundle of rights conception of property - and it is eminently possible to comprehend the freehold estate as a 'bundle' or collection of different rights - the concept loses its potency where it is used in an explanatory way to articulate the nature of property itself. Penner, for example, argues that the 'bundle of rights' does not resolve the question of the content of property rights. Indeed, Penner suggests that such a conception falls into the trap of comprehending property as a thing, rather than as the means of regulation of relations concerning a thing: 'the bundle of rights view does not get us beyond the obligation to understand property in terms of a right to a thing., ${ }^{37}$

\footnotetext{
${ }^{36}$ Babie (2016), p 611.

${ }^{37}$ Penner (1996), p 733.
} 
In what Penner describes as a 'disaggregative version' of the bundle of rights approach to property, the notion of property is constructed from the aggregation of each possible use for that thing. ${ }^{38}$

The difference between the two concepts of property can be put in this way: We actually conceive of property in terms of a right which permits an owner to do anything or nothing with his property; the disaggregative bundle of rights thesis insists that an owner may do everything with his property. The former view accords with the fact that the law of property takes no interest in the particular use one makes of one's property (which is not to say that criminal law or the law of taxation does not); the latter holds that the essence of property is an infinite number of rights to use a thing, in the same way that the Hohfeldian idea of a right in rem entails having millions of rights against all other people. ${ }^{39}$

If Babie's contention is that a right to build forms part of the bundle of rights comprising the freehold estate, Penner's disaggregative approach appears to describe Babie's explanation of the right to build. It would also comprehend his suggestion that regulation is property in that each time a government edict affected any conceivable use of the land concerned, that regulation represents part of the bundle of rights that 'is' property in that land. 'This view emphasizes in the strongest fashion that the very nature of property is that of an infinitely divisible composite, which can be disintegrated into or built up from less extensive rights. ${ }^{40}$

By contrast, Penner prefers an account of property as a 'unified legal relation'. ${ }^{41}$ While there are descriptive elements of the bundle of rights theory that serve to explain the nature of freehold interests, understanding the estate as a unified whole better reflects the state of the

\footnotetext{
${ }^{38}$ Penner (1996), p 734.

${ }^{39}$ Penner (1996), p758.

${ }^{40}$ Penner (1996), p 734.

${ }^{41}$ Penner (1996), p 739.
} 
law of real property. In particular, it supports my own contention that however we describe the component rights of the freehold owner, those rights are established by the State through its original grant in fee simple.

As Babie says, 'the quibble here is not about regulation, but about where it resides. ${ }^{42}$ Both Babie and I acknowledge the power of the State to regulate, and acknowledge that regulation will affect the choices landowners have in relation to their activities on their land. However, his argument appears to reflect a disaggregation approach which contemplates regulation within the content of an extensive (indeed infinite) array of property rights affecting use of the thing, while my own situates regulation outside the real property interest per se.

As a question of law, there is little to support a contention that a 'right to build' or a development right, is real property. Despite the freehold estate comprising or contemplating a number of rights, the argument in my blog post was predicated on the understanding of property in the freehold estate as a unified whole, bounded by the State's grant. The exercise of human activity in relation to the land the subject of that grant was always to be open to State regulation — as is all human behaviour, consequent on the power inherent in the State. Such regulation need not occur within the conception of property itself.

\section{Permissions as Property: Honore's Incidents}

While the right to build is unlikely to form part of the rights comprising property in the freehold estate, Babie's argument might also be interpreted to imply that a right to build was of itself a property right, independent of property in the land itself. ${ }^{43}$ Babie refers to Honore's incidents

\footnotetext{
${ }^{42}$ Babie (2016), p 612.

${ }^{43}$ Along the lines of Reich (1963).
} 
of property ${ }^{44}$ in a couple of instances,${ }^{45}$ to support his contention that property is intrinsically constrained by what he calls the choice architecture of the law.

Honore's incidents include the right to possess; to use, manage and receive income; to capital; to alienate; to security; of transmissibility and absence of term; prohibition of harmful use; and the liability to execution. ${ }^{46}$ These incidents are reflected in Babie's article, narrowed down to three general characteristics — use, exclusivity, and disposition. ${ }^{47}$ I suggest, however, that it is difficult to situate a right to build even within this conceptualisation of property. This is so whether one attempts to identify a right to build on land as property, but especially so if it is conceived of as being divorced from other incidents of property in land - or indeed, from the land itself.

It is useful first to observe that a property right regulates relations between people in relation to a thing. It is thus enforceable against all others-hence Babie's conception of property includes exclusivity. ${ }^{48}$ The right to build however, is not a right enforceable against the world - it does not lie in rem. ${ }^{49}$ It exists only as between the local authority and the land owner. It cannot be a right in rem, as it does not '[entail] having millions of rights against all other people' ${ }^{50}$ The exercise of planning rights occurs through local (or state) government processes, which themselves comprise planning law or administrative law where an executive decision is taken. This characterises planning law, including any right to build, as the imposition of government discretion not only to grant the right, but to refuse it also, or to circumscribe it, as an exercise of government power vis-à-vis the land owner.

\footnotetext{
${ }^{44}$ Honore (1961).

${ }^{45}$ Babie (2016), pp 605, 606.

${ }^{46}$ Honore (1961).

${ }^{47}$ Babie (2016), p 605, citing Radin (1993).

${ }^{48}$ Babie (2016), p 605.

${ }^{49}$ Ryan (1988), pp 56-57.

50 Penner (1996), p 758.
} 
A preferable characterisation of such a right is as a planning right and Penner's case study of licences - 'the owner's changing the contour of the right to exclude in order to facilitate someone else's use ${ }^{51}$ _ illustrates the potential for the content of non-property interests to elide with property proper. A planning permission might be construed as stemming from, or affecting the right to exclude — and to permit — possession of land. However, adopting Penner's argument, a planning provision need not 'pre-exist [its] creation'. It is 'created de novo'. ${ }^{52}$

If planning provisions are indeed de novo permissions or restrictions (as the case may be), their character is very different from that of property despite sharing appearances. My preference for Penner's argument, however, directly contrasts with that of Babie, who maintains that 'the right to develop always existed; its scope was merely expanded and narrowed by Seeney and Trad respectively.' ${ }^{53}$ While Babie is entitled to hold a different view, it is incorrect to assert that the argument in my original post supports the contention that regulation is in fact property.

To advance the argument, and to test whether the right to build might itself be property, it is possible to analyse it using Honore's incidents of property. To the extent that the right to build involves a right to possession, it arises from the estate in land. Unlike the transferrable floor rights in Immer, the right cannot be alienated separately from the estate, and there is no attendant possibility of income from the right. Such rights bear no relationship to any right to build which is distinct from real property and its incidents.

The right to security implies that ownership continues for as long as the owner chooses, and remains solvent. ${ }^{54}$ This is not present in a right to build. Likewise, and again, unlike the

\footnotetext{
${ }^{51}$ Penner (1996), p 759.

52 Penner (1996), p759.

${ }^{53}$ Babie (2016), p 611. Jackie Trad was the successor minister to Jeff Seeney, who subsequently overturned Seeney's Direction and reinstated the Council's own restrictions on building.

${ }^{54}$ Penner (1996)Error! Bookmark not defined., p 760.
} 
rights in question in Immer, there is no right to transmit the right to build. While the owner of an estate in fee simple might transfer that estate including any development approvals, the socalled right to build as an 'interest' is not of itself transferred or transferrable.

Liability to execution is likely to be the closest argument to suggesting that a right to build is property, and Babie acknowledges it as relevant. ${ }^{55}$ Indeed its removal by state fiat is what prompted the Minister's original statement and this discussion. However, while a right to build might well be denied by government, or amended or revoked by planning instrument (as occurred in the case study analysed here), this can hardly be said to be a liability to execution. The taking away of building rights cannot be understood as government expropriation even where such removal is done for the greater good. Certainly, there is no way for such rights to be seised and sold to pay owners' debts.

The absence of compensation goes to the heart of the characterisation of building and planning regulations as planning law and not land law. The nature of property is such that generally there are constraints upon state takings - even if only in terms of compensation. ${ }^{56}$ No such compensation exists for building rights in the Moreton Regional Council area. While this is admittedly a somewhat circular argument, the law that underpins this case study provides no support for a contention that a right to build comprises either a bundle of rights on its own account, or that it forms part of a larger bundle of rights inherent in the estate. This is reinforced by the nature of planning rights themselves.

\section{The Nature and 'Content' of Planning Rights}

The conceptualisation of a building right as inherent in real property, or as property itself, not only misconstrues the nature of property, but also misconstrues the nature of permissions

\footnotetext{
${ }^{55}$ Babie (2016), p 606, at footnote 37.

${ }^{56}$ See, eg, Longo (1983); O’Connor (2010).
} 
obtainable under a planning instrument. Despite an inevitable tendency of land owners to perceive of such permissions as part of their domain, the law itself differentiates property and such rights. This was the point of my original post.

This is not to say that property theory might offer ways of understanding property including as performative expressions of social norms. ${ }^{57}$ Through such theoretical means it is possible to articulate how the law might comprehend quite diverse rights - awarded or repealed as part of choice architecture-as property. However, the power of the law and its operation circumscribes the nature and content of real property as a legal category, regardless of its effect upon the choices exercised by owners (or others) in relation to land.

Reich in his seminal article might thus suggest that a planning permission be regarded as 'the new' property. His thesis is that government largesse-'benefits, services, contracts, franchises, and licences ${ }^{, 58}$ _ ought to constitute property. His justification is the shift of the source of wealth over time from land, to government concessions. His argument is fascinating, and there are echoes of his justification implicit in Babie's contention that 'regulation is property'. Certainly, I have sympathy with Reich's contention and there are economic, political, and social reasons why the conception of property, including as it is reflected in the law, is overdue for change. However, before this change occurs, the law is clear about the categorisation of planning law_as distinct from property.

It is in the nature of planning that it may add to the value of land as well as decrease it. There is considerable scholarly discussion ${ }^{59}$ around the question of whether planning regulation is a taking - a question implying that the regulation constitutes a diminution of property. Generally, however, in Australian state jurisdictions, even regulation that

\footnotetext{
${ }^{57}$ See, eg, Blomley (2013).

${ }^{58}$ Reich (1963), p 733.

${ }^{59} \mathrm{See}$, eg, discussion in O’Connor (2010).
} 
significantly imposes on the owner's use of land will not attract compensation without statutory provision. ${ }^{60}$ Even where compensation is available, the right does not necessarily derive from the fact of property. Longo, for example, argues that compensation is more about fulfilling the 'State's responsibility or role as the dominant source of property rights or wealth.' ${ }^{61}$ He thus suggests that compensation arises from this responsibility rather than as an indicator of property.

In Queensland, the Planning Act 2016 does now provide for compensation for an 'adverse planning change ${ }^{62}$ - where there is a change to a planning instrument that limits the use of premises to '(a) the purpose for which the premises were lawfully being used when the change was made; or (b) a public purpose'. ${ }^{63}$ While this might include such changes as proposed by the Moreton Regional Council originally_limiting owners' capacity to build on their land - the fact of compensation does not necessarily reveal a property interest. The framing of the provisions do, however, recognise the diminution of value of the land. Although the reason for a diminution of value might be the loss of some kind of property right that was previously inherent in the estate, as Babie might argue, it might simply recognise the loss of the permission to build. The argument in favour of property is not advanced by a provision of compensation. Such government action might affect how one uses one's real property, but that does not equate the thing lost to characterisation as property.

\section{The Diversion of Climate Change}

\footnotetext{
60 See generally, Gray (2007).

${ }^{61}$ Longo (2983), p 294.

${ }^{62}$ Generally, in Part 4, Division 1.

${ }^{63}$ Planning Act 2016 (Qld), s30. This provision post-dates my original post, but is used here for the purposes of illustration.
} 
Babie identifies the theme of my blog post as climate change - a theme that takes 'centre stage'. ${ }^{64}$ Indeed, the Moreton Regional Council changed its planning laws to avoid potential liability for any land-owner losses associated with rising sea levels consequent on climate change. And, it was the then-Minister's requirement that councils not make any reference to climate change, that informed the Minister's Directive to change the building rules. In turn, I observed that the Minister's approach was at odds with commercial realities concerning the effects and costs of climate change.

Integral to Babie's argument is the point that 'private property facilitates the choices (both human and corporate) about the use of goods and resources in such a way as to drive this enhanced greenhouse effect.' ${ }^{65}$ To this extent, he suggests that '[r]egulation, then, whether direct or indirect, forms part of the choice architecture of property, and it can, and does, take as its motivation the mitigation of or adaptation to the consequences of climate change. ${ }^{66}$

Again, there are two possible interpretations of Babie's linking of private property regulation and climate change. On the one hand, he seems to suggest that regulation of private property might prevent, or inhibit, or at least not exacerbate the drivers of climate change such as greenhouse gases and warming. ${ }^{67}$ On the other, he suggests that such regulation will mitigate the consequences of climate change: desertification, increased frequency of extreme weather events, melting polar ice, and rising sea levels, ${ }^{68}$ with flow on effects of 'decreasing security, shortages of food, increased health problems, and greater stress on available water supplies. ${ }^{69}$ He says: 'In short, Galloway points to the role that the state may play in restricting property in

\footnotetext{
${ }^{64}$ Babie (2016), p 604.

${ }^{65}$ Babie (2016), p 609.

${ }^{66}$ Babie (2016), p 609.

${ }^{67}$ Babie (2016), p 609.

${ }^{68}$ Babie (2016), p 609.

${ }^{69}$ Babie (2016), p 610.
} 
order to respond to the challenge or (sic) climate change. ${ }^{70}$ I understand him to mean that the challenges of climate change include the important consequences listed above.

For the sake of clarity, my original post did not go further than to identify the concerns of the Moreton Regional Council with liability arising from landowner losses accompanying sea-level rises. I did not contend that preventing building approvals for land likely to be affected by sea-level change would constitute measures to prevent climate change or its direct consequences.

If liability for planning approvals on inundated land is a 'consequence of climate change' then my arguments do encompass such consequences. However, the primary consequences of climate change would be the sea-level rises themselves, along with rising sea temperatures and the other physical manifestations Babie identifies. Because of the economic consequences of these physical changes, there would be legal consequences-and it was these legal consequences that formed the backdrop to my post. I would not normally characterise such problems as a 'consequence of climate change', but accept that the law will need to grapple with a multitude of challenges.

For these purposes, my point is rather that it is a long bow to draw to link the arguments in my blog post with analysis of property as a means of mitigating climate change per se. The fact of permission to build - anywhere - will not of itself alter the changing climate. What I wrote about climate change instead served to identify the challenges for local authorities in regulating land use in the face of likely losses consequent upon sea-level rise. In particular, Seeney's view about property — and some fulsome right to build or develop — is at the front line of disputes about the extent of government power to regulate the use of land, and the

\footnotetext{
${ }^{70}$ Babie (2016), p 603.
} 
disquiet of freehold land owners at the prospect of having their behaviour regulated — even as they themselves stand to lose in the face of a rising sea.

\section{Conclusion}

Although I have here explained why I disagree with Babie's interpretation of my argument, Babie and I do have more in common than we differ. We agree that the State constructs the boundaries of real property, and that the State retains the power to alter the way in which real property is used. We agree that effective regulation has an important role in mitigating the relentless march of climate change, and also in preparing communities for primary and secondary consequences. We might be said to agree on the concept of property. ${ }^{71}$

Despite Babie's interpretation of my argument as one that aligns with his contention that

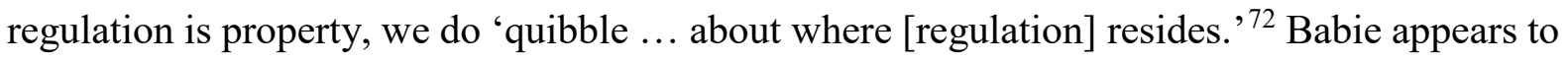
have it as the source of property per se, though whether that conception is real property or some other property interest, I cannot say. His argument is based on an abstracted conception of property in general, while my own conception of real property rests upon the law as written. In this article, I have further clarified my conception by referring to Penner's view on property rights as a 'unified whole'. ${ }^{73}$

Waldron might explain the difference between Babie's account and my account as representing different conceptions of property, ${ }^{74}$ where we share the concept in common. Such different conceptions are, in my view, inevitable and useful. By contrast, little is served by

\footnotetext{
${ }^{71}$ Waldron (1985).

${ }^{72}$ Babie (2016), p 612.

${ }^{73}$ Penner (1996).

${ }^{74}$ Jeremy Waldron, 'What is Private Property? (1985) 5 Oxford Journal of Legal Studies 313, 317.
} 
denying that property might be conceived of differently according to diverse method and theorisation.

There is no doubt that property and the markets it serves warrant scrutiny in terms of their effect on environmental destruction, including climate change. It is true that the way in which planning law is constructed and applied could do better at supporting environmental ends. ${ }^{75}$ However, the very issue that Babie purports to describe, namely that there is not only a relationship between planning regulation and property but that they are the same thing, is a conceptualisation that runs counter to the existing framework of the law. The law itself generates the very environmental challenges that we seek to overcome, notably from the fact of the separation of property and planning; from property and environmental concerns. This is no theoretical separation. Rather, it is a question of law and its taxonomies. This was the uncomplicated purpose of my original post.

\title{
Reference List
}

\author{
Primary Sources \\ Commonwealth $v$ New South Wales (1923) 33 CLR 1.
}

Gumana v Northern Territory (2007) 158 FCR 349

Immer (No 145) Pty Ltd v Uniting Church of Australia Property Trust (NSW) (1992/93) 182 CLR 26

Mabo v Queensland (No 2) (1992) 175 CLR 1

Peldan v Anderson (2006) 227 CLR 471.

Radaich v Smith (1959) 101 CLR 209.

\footnotetext{
${ }^{75}$ See, eg, Kate Galloway, 'Coast and Country Association of Queensland Inc v Minister for Environment and Heritage Protection' in Nicole Rogers and Michelle Maloney (eds), Law as If the Earth Really Mattered: The Wild Law Judgment Project (Routledge, 2017) 161.
} 
Uniting Church of Australia Property Trust (NSW) v Immer (No 145) Pty Ltd (1991) 24 NSWLR 510

Walsingham's Case (1573) 2 Plowd 547, 555.

Wright v Gibbons (1949) 78 CLR 313

\section{Legislation}

Geothermal Energy Act 2010 (Qld)

Greenhouse Gas Storage Act 2009 (Q1d)

Land Act 1994 (Qld)

Planning Act 2016 (Qld)

Property Law Act 1974 (Qld)

\section{Secondary Sources}

Paul Babie (2016) 'Three Tales of Property, or One?' 25(4) Griffith Law Review 600

Nicholas Blomley (2013) 'Performing Property, Making the World' 26 Canadian Journal of Law and Jurisprudence 23

William Blackstone (1765-1769) Commentaries on the Laws of England

Sharon A Christensen et al (2008) 'Early Land Grants and Reservations: Any Lessons from the Queensland Experience for the Sustainability Challenge to Land Ownership' 15(2) James Cook University Law Review 42.

Brendan Edgeworth (2017) Butt's Land Law, LawBook Co

Kate Galloway (2012) 'Landowners’ vs Miners' Property Interests: The Unsustainability of Property as Dominion' 37(2) Alternative Law Journal 1

Kate Galloway (2014) 'Planning Law is Not Property: Sea Level Change in Queensland' https://katgallow.blogspot.com.au/2014/12/planning-law-is-not-property-sea-level.html

Kate Galloway (2015) ‘Sustainability in the Real Property Law Curriculum: Why and How’ 8(2) Journal of Learning Design 31

Kevin Gray (2007) ‘Can Environmental Regulation Constitute a Taking of Property at Common Law?’ 24 Environmental and Planning Law Journal 161 
Kate Galloway (2017) 'Coast and Country Association of Queensland Inc v Minister for Environment and

Heritage Protection' in Nicole Rogers and Michelle Maloney (eds), Law as If the Earth Really Mattered: The Wild Law Judgment Project, Routledge.

A M Honore (1961) 'Ownership' in A G Guest (ed), Oxford Essays in Jurisprudence, Oxford University Press. Joseph Longo (1983) 'The Concept of Private Property and the Concept of Compensation on Compulsory Acquisition of Land' University of Tasmania Law Review 279

Frederick William Maitland (1909) 'The Mystery of Seisin' in Select Essays in Anglo-American Legal History, Little, Brown, \& Company.

Pamela O'Connor (2010) 'The Changing Paradigm of Property and the Framing of Regulation as a "Taking"” 36(2) Monash University Law Review 50.

J E Penner (1996) ‘The “Bundle of Rights” Picture of Property’ 43 UCLA Law Review 711.

Margaret Jane Radin (1993) Reinterpreting Property, University of Chicago Press

Charles Reich (1963) 'The New Property' 73 Yale Law Journal 733.

Kristy Richardson and Kate Galloway (2009) ‘Severing a Joint Tenancy: A Queensland Analysis’ 16 Australian Property Law Journal 245

Patricia Ryan (1988) 'Freedom of Property_An Urban Planning Perspective' 11 UNSW Law Journal 48 Jeremy Waldron (1985) 'What is Private Property?’ 5 Oxford Journal of Legal Studies 313 